\title{
The effects of the association of placenta previa and placenta accreta on the short-term maternal morbidity
}

\author{
Şener Gezer' (D), Mehmet Zeki Türe' ${ }^{1}$ (D) , Sibel Balcı² (D) , İzzet Yücesoy' \\ ${ }^{1}$ Department of Gynecology and Obstetrics, Faculty of Medicine, Kocaeli University, Kocaeli, Turkey \\ ${ }^{2}$ Department of Biostatistics and Medical Informatics, Faculty of Medicine, Kocaeli University, Kocaeli, Turkey
}

\begin{abstract}
Objective: We aimed to compare the effects of placenta previa (PP) and placenta accreta $(\mathrm{PA})$ on the short-term maternal morbidity alone and together.

Methods: The data of the patients who were diagnosed with PP, PA or placenta previa accreta (PPA) which includes both of them between January 2010 and December 2018 in a tertiary reference center were analyzed retrospectively. The records of the patients were compared between 3 groups for age, gravida, parity, week of gestation, previous cesarean section, history of curettage and myomectomy, gestational complications, placental location, hospitalization at hospital and intensive care unit, decreased level of hemoglobin, blood product transfusions, procedures to control bleeding and complications.

Results: Six out of 192 patients were excluded from the study as they delivered in other hospitals, and the data of 186 patients were analyzed. There were 141 (75.8\%) patients with PP only, 9 (4.8\%) patients with PA only, and 36 (19.4\%) patients with PPA. The erythrocyte transfusion was significantly higher in PPA patients than PP patients $(p<0.001)$. The possibility for the transfusion of any blood product was lower in PP group than other groups. While the rate of hospitalization at intensive care unit was higher in PPA group, the number of hospitalization day at hospital was significantly lower in PP group than PA $(\mathrm{p}=0.042)$ and PPA $(\mathrm{p}<0.001)$ groups. Urinary complication was observed less in PP patients. The hysterectomy rate was higher in PPA patients with than PP and PA patients $(\mathrm{p}=0.004)$.

Conclusion: The rates of maternal morbidity and hysterectomy increase when $\mathrm{PP}$ and $\mathrm{PA}$ are together compared to the cases where they are alone.
\end{abstract}

Keywords: Placenta previa, placenta accreta, maternal morbidity.

\section{Özet: Plasenta previa ve plasenta akreta birlikteliğinin kısa dönem maternal morbiditeye etkileri}

Amaç: Bu çalışmada plasenta previa (PP) ve plasenta akretanın (PA) tek başına ve birlikteliklerinde kısa dönem maternal morbiditeye etkilerini karşılaştırmayı hedefledik.

Yöntem: Üçüncü basamak referans merkezinde Ocak 2010 - Aralık 2018 tarihleri arasında tanısı konan PP, PA veya her ikisini birlikte içeren plasenta previa akreta (PPA) hastalarının verileri retrospektif olarak analiz edildi. Hasta kayıtları yaş, gravida, parite, gestasyon haftası, geçirilmiş sezaryen, küretaj ve miyomektomi öyküsü, gebelik komplikasyonları, plasenta lokasyonu, hastane ve yoğun bakım yatış1, hemoglobin düşüşü, kan ürünü transfüzyonları, kanama kontrolü için yapılan girişimler, komplikasyonlar için 3 grup arasında karşılaştrildi.

Bulgular: Toplam 192 hasta içerisinden altı hasta, doğumları başka hastanelerde gerçekleștiği için çalışma dışı bırakıldı ve 186 hastanın verileri analiz edildi. Sadece PP olan 141 (\%75.8) hasta, sadece PA olan 9 (\%4.8) hasta ve PPA olan 36 (\% 19.4) hasta mevcuttu. Eritrosit transfüzyonu PPA hastalarında, PP hastalarından anlamlı olarak daha yüksekti $(\mathrm{p}<0.001)$. Herhangi bir kan ürünü transfüzyonu olasılığ 1 PP'de diğer gruplara göre daha azdı. Yoğun bakım yatış oranı PPA grubunda daha fazla iken, hastanede yatış günü sayısı $\mathrm{PP}$ grubunda, $\mathrm{PA}(\mathrm{p}=0.042)$ ve $\mathrm{PPA}$ gruplarından $(\mathrm{p}<0.001)$ anlamlı olarak daha düşüktü. Üriner komplikasyona PP hastalarında daha az rastlandi. PPA hastalarında histerektomi oran1, PP ve PA hastalarına göre daha fazla bulundu ( $\mathrm{p}=0.004)$.

Sonuç: PP ve PA'nın tek başına bulunmasına göre birlikteliklerinde kısa dönem maternal morbidite ve histerektomi oranları artmaktadır.

Anahtar sözcükler: Plasenta previa, plasenta akreta, maternal morbidite.

Correspondence: Şener Gezer, MD. Department of Gynecology and Obstetrics, Faculty of Medicine, Kocaeli University, Kocaeli, Turkey. e-mail: dr.senergezer@gmail.com / Received: July 5, 2020; Accepted: August 25, 2020

Please cite this article as: Gezer S, Türe MZ, Balcı S, Yücesoy İ. The effects of the association of placenta previa and placenta accreta on the short-term maternal morbidity. Perinatal Journal 2020;28(3):176-182. doi:10.2399/prn.20.0283006 


\section{Introduction}

Placenta previa is the condition where placenta covers cervical os, and it is defined in three types according to how placenta covers cervical os: (1) in placenta previa totalis, the placenta covers internal cervical os completely; (2) in placenta previa partialis, the placenta covers internal cervical os partially; (3) in placenta previa marginalis, the placenta is associated with internal cervical os, but it does not cover cervical os. The prevalence rates of $\mathrm{PP}$ are reported between $0.35 \%$ and $0.6 \%$ in the literature. ${ }^{[1]}$ The risk factors of $\mathrm{PP}$ are the uterine surgery, maternal age above 35 , history of recurrent miscarriage, grand multiparity, infertility treatment and smoking. ${ }^{[2]}$

Placenta accreta $(\mathrm{PA})$ is formed by the invasion of placenta into myometrium in different grades in the absence of decidua basalis. It is called accreta if the invasion stays on decidual layer, increta if it reaches to myometrium, and percreta if it reaches to serosa. PA is one of the most common reasons for cesarean hysterectomy. ${ }^{[3]}$ While previous cesarean section is an important risk factor for $\mathrm{PA}$, it is also one of the reason for the increased incidence of PA. PP increases PA risk as well. ${ }^{[4]}$

$\mathrm{PP}$ and PA can be seen usually in the patients with the history of previous cesarean section together, and the patients with placenta previa accreta (PPA) are the ones with the highest risk in the accreta spectrum. ${ }^{[5]} \mathrm{In}$ the case of PPA, placental tissue may increase morbidity by moving towards the deep regions of pelvis and covering entire surgical site. ${ }^{[6]} \mathrm{PA}$ rates were reported between $1.18 \%$ and $9.3 \%$ in PP case series. ${ }^{[7,8]}$ In a meta-analysis where PP median prevalence was $0.56 \%$, PPA prevalence was reported $0.07 \% .{ }^{[9]}$ It was reported that PPA risk increased in line with the previous cesarean section and it could reach up to $40 \%$ in PP patients who undergo cesarean section for a third time. ${ }^{[10]}$

Hemorrhagic morbidity increases in PPA compared to PP or PA, and there are few numbers of studies in the literature comparing PPA with $\mathrm{PP}^{[11]}$ and PA. ${ }^{[12]}$ In our study, we aimed to compare the effects of $\mathrm{PP}$ and PA alone and together with PPA on the shortterm maternal morbidity.

\section{Methods}

In this study, the data of the patients who were diagnosed with PP, PA or PPA which includes both of them between January 2010 and December 2018 in a tertiary reference center were analyzed retrospectively. The study was conducted in accordance with the recent updates of Helsinki Declaration and the Regulation of Patient Rights after obtaining the approval of the ethics committee (KU GOKAEK 2018/377). Considering the retrospective nature of the study, informed consent step was waived. The records of the patients were reviewed in terms of age, gravida, parity, week of gestation, previous cesarean section, history of curettage and myomectomy, gestational complications, placental location, hospitalization at hospital and intensive care unit, decreased level of hemoglobin, blood product transfusions, procedures to control bleeding and complications. The data of the patients were compared for 3 groups which were PP, PA and PPA. All patients were evaluated by a perinatology specialist during antenatal period using ultrasonography and color Doppler examination. PP was graded and classified according to the ultrasonography findings. PA diagnosis was established during cesarean section when placenta was removed piece by piece as cleavage could not be found between uterine and placenta and when placental bed was stitched to control the bleeding or by histological confirmation when hysterectomy was carried out. The increased placental lacunes, the loss of hypoechoic retroplacental zone, disruption of the line between bladder and uterine, increased subplacental vascularity, irregular bridging vessels, and reduced retroplacental myometrial thickness were considered as the findings consistent with PA in the antenatal ultrasonography. Magnetic resonance imaging (MRI) was recommended for the patients with suspected diagnosis.

The primary objective of the study was to investigate if there is any difference between PP, PA and PPA groups or not in terms of short-term maternal morbidity, obstetric management and complication rates.

\section{Statistical analysis}

All statistical analyses were conducted by using IBM SPSS for Windows version 20.0 (SPSS, Chicago, IL, USA). Kolmogorov-Smirnov and Shapiro-Wilk tests were used to asses normality assumption. Constant variables were presented as mean \pm standard deviation depending on normal distribution or median (25-75th percentile) (in case of the absence of normal distribution). Categorical variables were presented as number (percentage). The constant variables between the groups were compared by using one-way variance analysis (ANOVA) and Kruskal-Wallis test. LSD test 
and Dunn test were used for multiple comparisons. The correlation between two categorical variables were evaluated by chi-square test. All statistical analyses were done with the significance value of $5 \%$, and bilateral p-value $<0.05$ was considered statistically significant.

\section{Results}

A total of 192 patients diagnosed with PP and/or PA were found in the retrospective file screening. Six patients were excluded from the study as they delivered in other hospitals, and the data of 186 patients were analyzed. There were $141(75.8 \%)$ patients with PP only, 9 (4.8\%) patients with PA only, and 36 (19.4\%) patients with PPA (Fig. 1). The sub-group analyses of PPA patients are shown in Table 1, and the demographic and clinical characteristics of the patients are shown in Table 2. It was seen in the pairwise comparisons done for the variables with significant differences between the groups that the ages of PP patients were significantly lower than PPA patients $(\mathrm{p}=0.002)$. Gravida number was significantly lower in PP patients than PPA patients $(\mathrm{p}<0.001)$. Parity number was also significantly lower in $\mathrm{PP}$ patients than $\mathrm{PA}$ patients $(\mathrm{p}=0.005)$ and PPA patients $(\mathrm{p}<0.001)$. The number of previous cesarean section was significantly lower in PP patients than PA patients $(\mathrm{p}<0.001)$ and PPA patients $(\mathrm{p}<0.001)$. The procedure duration was significantly lower in PP patients than PPA patients $(\mathrm{p}<0.001)$

The comparison of the morbidities by the groups is presented in Table 3. As a result of the pairwise comparisons done for the variables with significant differences between the groups, it was found that erythrocyte transfusion was significantly higher in PPA patients than PP patients $(\mathrm{p}<0.001)$. The possibility for the transfusion

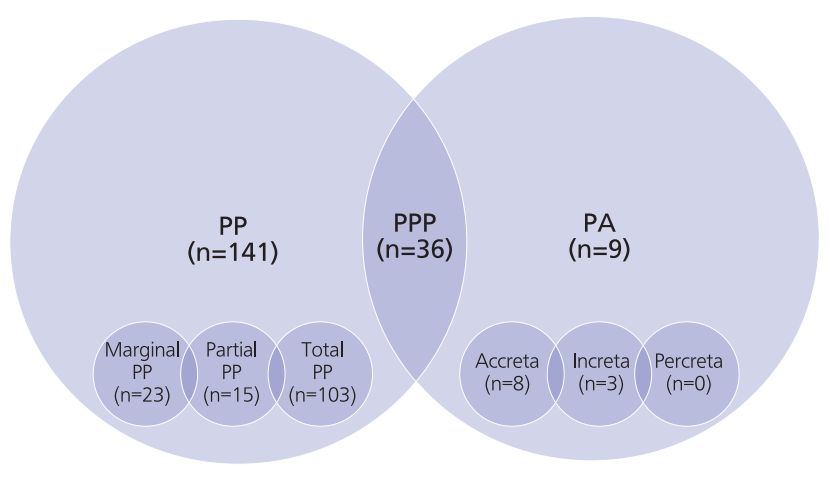

Fig. 1. Distribution of patients by groups. PA: Placenta accreta; PP: Placenta previa; PPA: Placenta previa accreta.

of any blood product was lower in PP group than other groups. While the rate of hospitalization at intensive care unit was higher in PPA group, the number of hospitalization day at hospital was significantly lower in PP group than PA $(\mathrm{p}=0.042)$ and PPA $(\mathrm{p}<0.001)$ groups. Urinary complication was observed less in PP patients. The hysterectomy rate was higher in PPA patients than $\mathrm{PP}$ and PA patients $(\mathrm{p}=0.004)$.

\section{Discussion}

Bleeding and intraoperative and short-term postoperative maternal complications can be seen more frequently in PP and PA patients than the patients without placental location and invasion anomaly. The possibility of both conditions being alone or together increases with the rate of previous cesarean section. In a meta-analysis, the authors found that the relative risk increased 4.5 times with the previous cesarean section, 7.2 times with second cesarean section, and 44.9 with fourth cesarean section for PP ${ }^{[13]}$ While PPA incidence

Table 1. The distribution of PPA sub-groups.

\begin{tabular}{|c|c|c|c|c|c|}
\hline & & \multicolumn{3}{|c|}{ PP sub-type n (\%) } & \multirow{2}{*}{ Total } \\
\hline & & Marginal & Partial & Total & \\
\hline \multirow[t]{3}{*}{ PA sub-type $n(\%)$} & Accreta & 0 & $2(8.3)$ & $22(91.7)$ & $24(100)$ \\
\hline & Increta & $2(50)$ & $1(25)$ & $1(25)$ & $4(100)$ \\
\hline & Percreta & 0 & 0 & $8(100)$ & $8(100)$ \\
\hline Total & & $2(100)$ & $3(100)$ & $31(100)$ & $36(100)$ \\
\hline
\end{tabular}

PA: placenta accreta; PP: placenta previa; PPA: placenta previa accreta. 
Table 2. Demographic and clinical data of the patients.

\begin{tabular}{|c|c|c|c|c|c|}
\hline & & $\begin{array}{c}P P \\
n=141\end{array}$ & $\begin{array}{c}P A \\
n=9\end{array}$ & $\begin{array}{c}\text { PPA } \\
n=36\end{array}$ & p-value \\
\hline Age (median 25-75) (year) & & $31(27-35)$ & $36(31-36.5)$ & $35(31-36)$ & 0.001 \\
\hline Gravida & & $3(2-4)$ & $4(3-5)$ & $4(3-5)$ & $<0.001$ \\
\hline Parity & & $1(0-2)$ & $3(2-3)$ & $2(2-2.7)$ & $<0.001$ \\
\hline Week of gestation & & $35(34-37)$ & $37(34-38)$ & $36(34-37.7)$ & 0.591 \\
\hline Previous cesarean section & & $0(0-1)$ & $2(2-2)$ & $2(1-2)$ & $<0.001$ \\
\hline Previous curettage & & $21(14.9 \%)$ & $2(22.2 \%)$ & $7(19.4 \%)$ & 0.696 \\
\hline Previous myomectomy & & $3(2.1 \%)$ & & & \\
\hline \multirow[t]{9}{*}{ Gestational complication } & Preeclampsia & $2(1.4 \%)$ & & & \\
\hline & Intrauterine growth restriction & $1(0.7 \%)$ & & & \\
\hline & Chronic hypertension & $2(1.4 \%)$ & & $1(2.8 \%)$ & \\
\hline & Gestational diabetes & $7(5 \%)$ & $1(11.1 \%)$ & $5(13.9 \%)$ & \\
\hline & Twin pregnancy & $1(0.7 \%)$ & & $1(2.8 \%)$ & \\
\hline & Morbid obesity & $1(2.8 \%)$ & & & \\
\hline & Epilepsy & $1(2.8 \%)$ & & & \\
\hline & In vitro fertilization pregnancy & $10(7.1 \%)$ & & & \\
\hline & Type 1 diabetes & & $1(11.1 \%)$ & & \\
\hline Antenatal hemorrhage & & $65(46.1 \%)$ & & $4(11.1 \%)$ & \\
\hline Emergency cesarean section & & $66(46.8 \%)$ & & $6(16.7 \%)$ & \\
\hline Surgery duration (min) & & $60(60-70)$ & $90(60-140)$ & $127(61-173)$ & $<0.001$ \\
\hline
\end{tabular}

PA: placenta accreta; PP: placenta previa; PPA: placenta previa accreta. Constant variables were presented as mean \pm standard deviation consistent with normal distribution and those not consistent as median (25-75th percentile), and the categorical variables were presented as number (percentage).

was reported $11 \%$ in patients who had $\mathrm{PP}$ and underwent cesarean section once, it was $61 \%$ in PP patients who had cesarean section for the third time. This risk is $3 \%$ in the absence of cesarean section history. However, the risk remains at $1 \%$ in the presence of 3 previous cesarean section without $\mathrm{PP} .{ }^{[4]}$ Miller et al. reported PPA rates $4 \%, 14 \%, 23 \%, 35 \%$, and $50 \%$ in $590 \mathrm{PP}$ patients for $0,1,2,3$, and 4 previous cesarean sections. ${ }^{[7]}$ In our study, we found that age, gravida, parity and increased cesarean section numbers were risk factors for PPA. While Lachman et al. ${ }^{[14]}$ found advanced maternal age as a very important factor, Zaki et al. ${ }^{[11]}$ defined age and parity as less significant factors than previous cesarean section. The curettage history is also a significant factor for PA and PA incidence was reported $36 \%, 58 \%$ and $70 \%$ for 0,2 and 3 curettage procedures, respectively. ${ }^{[15]}$ However, we could not find any difference between the groups in terms of curettage history.
Usta et al. compared $325 \mathrm{PP}$ patients with $22 \mathrm{PPA}$ patients in their study, and found that estimated blood loss, need for transfusion and hospitalization were higher in PPA patients. ${ }^{[8]}$ In their study, hypogastric artery ligation and hysterectomy were carried out only in PPA patients. In the logistic regression analysis, hypertension disease and previous cesarean section were found as the factors that can predict PA development. Another study found that postpartum bleeding and hysterectomy were significantly higher in PPA group than PP group. ${ }^{[1]}$ Similarly, blood transfusion and hospitalization duration were higher in PPA group, but there were no difference in terms of perinatal outcomes and fetal weight. In a study investigating hemorrhagic morbidity in PA patients, the authors reported that the comorbidity of PP increased estimated blood loss and erythrocyte transfusion, and it increased hysterectomy risk 2.7 times and hospitalization at intensive care unit 3.3 times. ${ }^{[12]}$ 
Table 3. Comparison of the morbidities by the groups.

\begin{tabular}{|c|c|c|c|c|c|}
\hline & & $\begin{array}{c}P P \\
n=141\end{array}$ & $\begin{array}{c}P A \\
n=9\end{array}$ & $\begin{array}{c}\text { PPA } \\
n=36\end{array}$ & p-value \\
\hline \multicolumn{2}{|c|}{ Preoperative hemoglobin } & $11.5+/-1.3$ & $11.6+/-0.9$ & $11.4+/-0.9$ & 0.710 \\
\hline \multicolumn{2}{|c|}{ Postoperative hemoglobin } & $10.3+/-1.4$ & $10+/-1.4$ & $11.4+/-0.9$ & 0.109 \\
\hline \multicolumn{2}{|c|}{ Hemoglobin decrease } & $1.1(0.3-1.9)$ & $1.4(0.5-2.8)$ & $1.6(1-2.5)$ & 0.138 \\
\hline \multicolumn{2}{|c|}{ Erythrocyte transfusion } & $2(1-4)$ & $2(1-11)$ & $4(3-7)$ & $<0.001$ \\
\hline \multicolumn{2}{|c|}{ Fresh frozen plasma transfusion } & $2(2-4)$ & $3(2-7)$ & $3(2-4.2)$ & \\
\hline \multicolumn{2}{|c|}{ Full blood transfusion } & $1.5(1-2)$ & $1(1-1)$ & $2(1.7-3.2)$ & \\
\hline \multicolumn{2}{|c|}{ Any transfusion } & $70(49.6 \%)$ & $7(77.8 \%)$ & $28(77.8 \%)$ & 0.003 \\
\hline \multicolumn{2}{|c|}{ Hospitalization at intensive care unit } & $14(9.9 \%)$ & $2(22.2 \%)$ & $13(36.1 \%)$ & 0.001 \\
\hline \multicolumn{2}{|c|}{ Intensive care days } & $1(1-1)$ & $1.5(1-1.75)$ & $1(1-2)$ & \\
\hline \multicolumn{2}{|c|}{ Hospitalization days } & $4(3-6)$ & $6(4.5-15.5)$ & $6(5-10)$ & $<0.001$ \\
\hline \multirow[t]{7}{*}{ Procedure } & Bakri balloon & $10(7.1 \%)$ & & $1(2.8 \%)$ & \\
\hline & Uterine artery ligation & $8(5.7 \%)$ & $1(11.1 \%)$ & $1(2.8 \%)$ & \\
\hline & Hypogastric artery ligation & $6(4.3 \%)$ & & $1(2.8 \%)$ & \\
\hline & Hysterectomy & $10(7.1 \%)$ & $3(33.3 \%)$ & $18(50 \%)$ & \\
\hline & Bakri balloon + uterine artery ligation & $3(2.1 \%)$ & $2(22.2 \%)$ & $1(2.8 \%)$ & \\
\hline & Bakri balloon + hypogastric artery ligation & $3(2.1 \%)$ & & $1(2.8 \%)$ & \\
\hline & Hysterectomy + hypogastric artery ligation & $1(0.7 \%)$ & & & \\
\hline \multicolumn{2}{|c|}{ Urinary complication } & $6(4.3 \%)$ & $2(22.2 \%)$ & $9(25 \%)$ & 0.002 \\
\hline \multicolumn{2}{|c|}{ Bladder injury } & $5(3.5 \%)$ & $1(11.1 \%)$ & $8(22.2 \%)$ & \\
\hline \multicolumn{2}{|c|}{ Ureter injury } & $1(0.7 \%)$ & $1(11.1 \%)$ & $1(2.8 \%)$ & \\
\hline
\end{tabular}

PA: placenta accreta; PP: placenta previa; PPA: placenta previa accreta. Constant variables were presented as mean \pm standard deviation consistent with normal distribution and those not consistent as median (25-75th percentile), and the categorical variables were presented as number (percentage)

The mean blood loss in a pregnancy complicated with PA is usually $2.5-3$ liters. ${ }^{[16,17]}$ The massive hemorrhage ( $\geq 5000 \mathrm{ml}$ estimated blood loss) and massive transfusion ( $\geq 10$ units erythrocyte transfusion) were observed more in PPA cases. ${ }^{[18]}$ The presence of PP alone even in the patients not within placenta accreta spectrum is an independent factor increasing erythrocyte transfusion and hysterectomy risks. ${ }^{[19]}$

PP sub-types also have different effects on hemorrhagic morbidity. Postpartum hemorrhage and hysterectomy incidence were significantly higher in the patients with total and partial PP than the patients with marginal and low-lying $\mathrm{PP}^{\left[{ }^{[20]}\right.}$

When PA diagnosis is established during antenatal period, hemorrhagic morbidity may decrease significantly. Ultrasonographic imaging and MRI to be carried out by an experienced user are the important necessities to achieve this objective ${ }^{[2]]}$ A recent meta-analysis reported the efficiency $90.9 \%$ for the ultrasonographic diagnosis of PPA in specific units. ${ }^{[5]}$ With the diagnosis established before labor, a better blood product preparation can be done, a better operation team can be established (i.e. invasive radiology, compatible hybrid operating room, obstetric anesthetist, urologist, gynecology oncologist, vascular surgeon), ureter catheterization can be done and planned cesarean section hysterectomy can be done to detach placental without performing any intervention. ${ }^{[22]}$ Bailit et al. reported massive blood transfusion rate 33\% and hysterectomy rate $92 \%$ in morbid placental attachment anomalies diagnosed prenatally. ${ }^{[23]}$ In another study, the authors reported transfusion rate $21 \%$ and hysterectomy rate as low as $3.5 \%$ in PA patients. However, only 8 patients received antenatal diagnosis in this study. ${ }^{[2]}$ The hysterectomy rates in our study were $33.3 \%$ for $\mathrm{PA}$, and $50 \%$ for PPA which were similar to the literature. ${ }^{[9]}$ If the invasion grade of placenta proceeds 
up to percreta, hysterectomy rate may increase 3 times more than accreta. ${ }^{[24]}$

Urinary system complication can be seen with a rate of $16.8 \%$ in PA patients. ${ }^{[25]}$ Bladder injury is usually seen as a result of direct invasion of placenta to the bladder or difficulties in cervix-bladder dissection, but ureter damage may also be seen as a result of intense hemorrhage or the loss of surgical planes. Ureteral stent application may help to prevent the injury. It was shown that establishing the diagnosis during antenatal period in PA patients could prevent urinary system damage. In this study, with regression analysis, it was concluded that antenatal diagnosis is a significant predictive marker to prevent urinary system damage. ${ }^{[26]}$

In our study, we did not observe maternal mortality, but the mortality rates associated with PA and PPA were reported between $3 \%$ and $10 \%$ in the literature. ${ }^{[2]}$ The absence of mortality may be associated with the fact that this study was conducted in a tertiary reference center, easy access to blood products, obstetric anesthesia and strong surgical team. Expert committees recommend the management of PA and PPA cases in the centers of excellence which offer multidisciplinary planning and management opportunities in order to decrease morbidity and mortality. ${ }^{[0,28,29]}$

The strength of the study is relatively high number of patients, and the weaknesses of the study are the retrospective design, the failure of generalizing results to low risk patients as the study is conducted in a reference center for PP and PA, absence of objective criteria for calculation of estimated blood loss and transfusion decision.

\section{Conclusion}

In our study, PA and PPA possibilities increased together with the increasing number of cesarean section. We found that erythrocyte transfusion, transfusion of any blood product, rate of hospitalization at intensive care unit and total number of hospitalization days were significantly higher in PPA patients than PP patients. Hysterectomy rate was higher in PPA patients than PP and PA groups. In conclusion, we concluded that the association of previa and accreta increased short-term maternal morbidity.

Conflicts of Interest: No conflicts declared.

\section{References}

1. Faiz AS, Ananth CV. Etiology and risk factors for placenta previa: an overview and meta-analysis of observational studies. J Matern Fetal Neonatal Med 2003;13:175-90. [PubMed] [CrossRef]

2. Gielchinsky Y, Rojansky N, Fasouliotis SJ, Ezra Y. Placenta accreta - summary of 10 years: a survey of 310 cases. Placenta 2002;23:210-4. [PubMed] [CrossRef]

3. Awan N, Bennett MJ, Walters WA. Emergency peripartum hysterectomy: a 10-year review at the Royal Hospital for Women, Sydney. Aust N Z J Obstet Gynaecol 2011;51:210-5. [PubMed] [CrossRef]

4. Silver RM, Landon MB, Rouse DJ, Leveno KJ, Spong CY, Thom EA, et al. Maternal morbidity associated with multiple repeat cesarean deliveries. Obstet Gynecol 2006;107:1226-32. [PubMed] [CrossRef]

5. Jauniaux E, Bhide A. Prenatal ultrasound diagnosis and outcome of placenta previa accreta after caesarean delivery: a systematic review and meta-analysis. Am J Obstet Gynecol 2017; 217:27-36. [PubMed] [CrossRef]

6. Silver RM, Fox KA, Barton JR, Abuhamad AZ, Simhan H, Huls CK, et al. Center of excellence for placenta accreta. Am J Obstet Gynecol 2015;212:561-8. [PubMed] [CrossRef]

7. Miller DA, Chollet JA, Goodwin TM. Clinical risk factors for placenta previa-placenta accreta. Am J Obstet Gynecol 1997; 177:210-4. [PubMed] [CrossRef]

8. Usta IM, Hobeika EM, AA Abu Musa, Gabriel GE, Nassar AH. Placenta previa-accreta: risk factors and complications. Am J Obstet Gynecol 2005;193:1045-9. [PubMed] [CrossRef]

9. Jauniaux E, Grønbeck L, Bunce C, Langhoff-Roos J, Collins SL. Epidemiology of placenta previa accreta: a systematic review and meta-analysis. BMJ Open 2019;9:e031193. [PubMed] [CrossRef]

10. Publications Committee, Society for Maternal-Fetal Medicine; Belfort MA. Placenta accreta. Am J Obstet Gynecol 2010;203: 430-9. [PubMed] [CrossRef]

11. Zaki ZM, Bahar AM, Ali ME, Albar HA, Gerias MA. Risk factors and morbidity in patients with placenta previa-accreta compared to placenta previa non-accreta. Acta Obstet Gynecol Scand 1998;77:391-4. [PubMed] [CrossRef]

12. Mulla BM, Weatherford R, Redhunt AM, Modest AM, Hacker MR, Hecht JL, et al. Hemorrhagic morbidity in placenta accreta spectrum with and without placenta previa. Arch Gynecol Obstet 2019;300:1601-6. [PubMed] [CrossRef]

13. Ananth CV, Smulian JC, Vintzileos AM. The association of placenta previa with history of cesarean delivery and abortion: a metaanalysis. Am J Obstet Gynecol 1997;177:1071-8. [PubMed] [CrossRef]

14. Lachman E, Mali A, Gino G, Burstein M, Stark M. Placenta accreta with placenta previa after previous cesarean section - a growing danger in modern obstetrics. [Article in Hebrew] Harefauh 2000;138:628-31. [PubMed]

15. Kastner ES, Figueroa R, Garry D, Maulik D. Emergency peripartum hysterectomy: experience at a community teaching hospital. Obstet Gynecol 2002;99:971-5. [PubMed] [CrossRef] 
16. Eller AG, Porter TF, Soisson AP, Silver RM. Optimal management strategies for placenta accreta. BJOG 2009;116:64854. [PubMed] [CrossRef]

17. Pri-Paz S, Fuchs KM, Gaddipati S, Lu YS, Wright JD, Devine PC. Comparison between emergent and elective delivery in women with placenta accreta. J Matern Fetal Neonatal Med 2013;26:1007-11. [PubMed] [CrossRef]

18. Wright JD, Pri-Paz S, Herzog TJ, Shah M, Bonanno C, Lewin $\mathrm{SN}$, et al. Predictors of massive blood loss in women with placenta accreta. Am J Obstet Gynecol 2011;205:38.e1-38.e6. [PubMed] [CrossRef]

19. Gibbins KJ, Einerson BD, Varner MW, Silver RM. Placenta previa and maternal hemorrhagic morbidity. J Matern Fetal Neonatal Med 2018;31:494-9. [PubMed] [CrossRef]

20. Bahar A, Abusham A, Eskandar M, Sobande A, Alsunaidi M. Risk factors and pregnancy outcome in different types of placenta previa. J Obstet Gynaecol Can 2009;31:126-31. [PubMed] [CrossRef]

21. Warshak CR, Ramos GA, Eskander R, Benirschke K, Saenz CS, Kelly TF, et al. Effect of predelivery diagnosis in 99 consecutive cases of placenta accreta. Obstet Gynecol 2010;115: 65-9. [PubMed] [CrossRef]

22. Balayla J, Bondarenko HD. Placenta accreta and the risk of adverse maternal and neonatal outcomes. J Perinat Med 2013; 41:141-9. [PubMed] [CrossRef]

23. Bailit JL, Grobman WA, Rice MM, Reddy UM, Wapner RJ, Varner MW, et al.; Eunice Kennedy Shriver National Institute of Child Health and Human Development (NICHD)
Maternal-Fetal Medicine Units (MFMU) Network. Morbidly adherent placenta treatments and outcomes. Obstet Gynecol 2015;125: 683-9. [PubMed] [CrossRef]

24. Marcellin L, Delorme P, Bonnet MP, Grange G, Kayem G, Tsatsaris $\mathrm{V}$, et al. Placenta percreta is associated with more frequent severe maternal morbidity than placenta accreta. Am J Obstet Gynecol 2018;219:193.e1-193.e9. [PubMed] [CrossRef]

25. Titapant V, Tongdee T, Pooliam J, Wataganara T. Retrospective analysis of 113 consecutive cases of placenta accreta spectrum from a single tertiary care center. J Matern Fetal Neonatal Med 2018;33;3324-31. [PubMed] [CrossRef]

26. Tam Tam BK, Dozier J, Martin Jr JN. Approaches to reduce urinary tract injury during management of placenta accreta, increta, and percreta: a systematic review. J Matern Fetal Neonatal Med 2012;25:329-34. [PubMed] [CrossRef]

27. Clausen C, Lonn L, Langhoff-Roos J. Management of placenta percreta: a review of published cases. Acta Obstet Gynecol Scand 2014;93:138-43. [PubMed] [CrossRef]

28. Eller AG, Bennett MA, Sharshiner M, Masheter C, Soisson AP, Dodson M, et al. Maternal morbidity in cases of placenta accreta managed by a multidisciplinary care team compared with standard obstetric care. Obstet Gynecol 2011;117:331-7. [PubMed] [CrossRef]

29. American College of Obstetricians and Gynecologists and Society for the Maternal-Fetal Medicine. Obstetrics care consensus no.7: placenta accreta spectrum. Obstet Gynecol 2018; 132:e259-e275. [PubMed] [CrossRef] 